\title{
Effects of Different Levels of Potassium Diformate on Growth Performance and Feed Utilization of Monosex Nile Tilapia (Oreochromis niloticus) Fingerlings
}

\author{
Eid, A. E.; K. Mohamed; B. A. Ali and N. M. Sayed \\ Faculty of agriculture, Suez Canal University, 41522, Ismaillia, Egypt
}

Received: $15 / 1 / 2014$

\begin{abstract}
Potassium diformate has demonstrated effectiveness in enhancing growth performance of terrestrial animals and improves the general health status of cultured animals by its stronger antimicrobial effect. Consequently, this study was conducted to determine the effects of dietary organic acid salts as (potassium diformate) on growth promoters for monosex Nile tilapia fingerlings. Four experimental diets with three different inclusion levels of potassium diformate (KDF) $(0.1,0.3$ and $0.5 \%)$ besides the control diet containing no KDF. A total of 120 tilapia, weighing approximately $5 \pm 0.5 \mathrm{~g}$, were divided equally between 4 different treatments with 3 replicates (10 fish / replicate). Fish were fed two times a day at rate $3 \%$ of body weight on a pelletized isonitrogenous diet containing $25 \%$ crude protein and isocaloric (gross energy $393 \mathrm{Kcal} / 100 \mathrm{~g}$ ). The results indicated that the addition of $0.3 \% \mathrm{KDF}$ had a significantly higher growth performance, feed conversion ratio, feed efficiency, feed intake and survival of monosex tilapia fingerlings, compared to the control group. In conclusion, these results revealed that using $0.3 \% \mathrm{KDF}$ was the best in terms of growth performance and economic analysis under this experimental condition.
\end{abstract}

Keywords: potassium diformate, growth performance, monosex, Nile tilapia.

\section{INTRODUCTION}

The human demand of fish consumption is increasing all over the world. Fish is about to become the main alternative source of animal protein. Nile tilapia, Oreochromis niloticus, is the predominant cultured species worldwide (Thodesen et al., 2011, 2012; Gjerde et al., 2012; El-Sayed et al., 2012). Tilapia aquaculture represents about $42 \%$ of world total aquaculture fish production, and about $64 \%$ of the total fish production in Egypt (GAFRD, 2011).

Potassium diformate (K-diformate, KDF) is odorless, low-corrosive, flow able (Hebeler et al., 2000) and dietary inclusion has demonstrated effectiveness in enhancing growth performance of terrestrial animals (Øverland et al., 2000; Canibe et al., 2001; Mroz et al., 2002). Consequently, KDF was the first substance approved as a possible nonantibiotic growth promoter by the European Union [Commission Reg (EC) number 1334/2001]. potassium diformate (KDF) improves the general health status of cultured animals by its stronger antimicrobial effect towards coliform bacteria than toward Lactobacilli (Lueck, 1980; Kirchgessner et al., 1992; Février et al., 2001), leading to a more favorable microbiota with lower population levels of Escherichia coli and Salmonella and higher population level and diversity of Lactobacilli (Hebeler et al., 2000). To our knowledge only one preliminary study on the inclusion of KDF in aquatic feed has been reported (Ramli et al., 2005) and its antimicrobial mode of action in aquatic animals is therefore unclear.

The aim of the present study was to investigate the effects of different levels of potassium diformate on growth performance and feed utilization of monosex Nile tilapia fingerlings and its effect on body composition with economic analysis.

\section{MATERIALS AND METHODS}

An experiment was conducted at fish Research center in Suez Canal University Ismaillia- Egypt to investigate the effect of dietary contain three levels of potassium diformate (KDF) $(0.1,0.3$ and $0.5 \%)$ in addition to control diet on growth performance, chemical body composition and economic analysis of monosex Nile tilapia (O. niloticus) fingerlings.

\section{Experimental units}

Fish were stocked in 12 plastic tanks $(80 \mathrm{~cm} \times 60 \mathrm{~cm}$ $\mathrm{x} 60 \mathrm{~cm}$ ) randomly divided into four equal experimental treatments (10 fish each tank, three replicate/ treatment). Tanks were supplied with air blowers. Photoperiod was

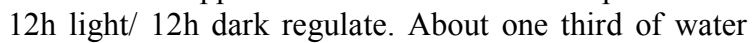
tank was exchanged with fresh water 2-3 time/week and totally changed with fresh water every 4 weeks.

Experimental fish

One hundred and twenty monosex Nile tilapia $(O$. niloticus) fingerlings with average initial weight of $5 \pm 0.5$ $\mathrm{g}$ which were obtained from El-Morshedy Brothers Company (Fish Hatchery), Abbassa, Abou Hammad, Sharkia, Egypt. Fish were homogenous in body weights and apparently healthy. Fish were acclimated to laboratory conditions for 2 weeks before the experiment start.

\section{Experimental diets}

Four isonitrogenous and isocaloric diets were formulated from practical ingredients (Table 1). The control diet had no addition of KDF while the other three diets were supplemented by $0.1,0.3$ and $0.5 \%$ potassium diformate for diets 2,3 and 4 respectively. The experimental diets were isonitrogenous containing $25 \%$ crude protein and isocaloric (gross energy 393 $\mathrm{Kcal} / 100 \mathrm{~g}$ ). The experimental diets were prepared by individually weighing of each component thoroughly mixing the mineral, vitamins and additives with corn. This mixture was added to the components together with oil. Water was added until the mixture became suitable for making pellets. The wet mixture was passed through CBM Pelleting machine with $2 \mathrm{~mm}$ diameter. The produced pellets were dried at room temperature and kept frozen until experimental start. The composition and proximate analysis of the experimental diets are 
presented in (Table 1). The fish were fed handly at rate $3 \%$ of body weight, twice/day (10 am and $4 \mathrm{pm})$ throughout the experimental period (84 days).

\section{Experimental Methodology}

At the beginning and the end of the experiment, sample of 5 fish were randomly taken from each experimental group for chemical analysis to determine body composition. The tested diets were analyzed for crude protein (CP \%) ether extract (EE \%), Crude fiber (CF \%), ash (\%) and moisture. While whole body composition of fish samples were also analyzed except crud fiber ( $\mathrm{CF} \%$ ) according to the procedures described by standard A. O. A. C. methods (1995). The nitrogen free-extract (NFE \%) was calculated by differences. Fish were weighed every two weeks and the average of 4 weeks was determined by UWE MJW-300 balance to the nearest $0.01 \mathrm{~g}$. The amount of feed was readjusted according to the new weight of fish. Water temperature and dissolved oxygen were measured daily using metteler Toledo, model 128.s/No1242. Other water quality including $\mathrm{pH}$ and ammonia were measured every two days by $\mathrm{pH}$ meter (Orion model 720A,s/no 13062) and ammonia meter by Hanna ammonia meter. Water quality parameters were within the acceptable range for Nile tilapia (Wilson, 1991).Water temperature ranged from 26.5 to $28.0{ }^{\circ} \mathrm{C}$ by using a 250 watt immersion heater with thermostat, DO from 5.7 to $6.3 \mathrm{mg} / \mathrm{L}, \mathrm{pH}$ from 6.8 to 7.9 and ammonia (NH3) from 0.23 to 0.29 $\mathrm{mg} / \mathrm{L}$.

\section{Growth performance parameters:}

The growth performance parameters were calculated according to the following equations:

\section{Average Weight Gain (AWG):}

$(\mathrm{AWG})=$ Average final weight $(\mathrm{g})$ - Average initial weight $(\mathrm{g})$

Specific Growth Rate (SGR \%/day):

$(\mathrm{SGR} \%$ / day $)=100[\mathrm{Ln} \mathrm{Wt1}-\mathrm{Ln} \mathrm{Wt} 0 / \mathrm{T}]$

Where: Ln: natural log

Wt 0: initial weight $(\mathrm{g})$

Wt 1: final weight $(\mathrm{g})$

$\mathrm{T}$ : time of days.

\section{Feed and protein utilization parameters:}

Feed and protein utilization parameters are calculated according to the following equations: -

Feed Conversion Ratio (FCR):

$\mathrm{FCR}=$ Total feed consumption $(\mathrm{g}) /$ weight gain $(\mathrm{g})$.

Feed Efficiency (FE):

$\mathrm{FE}=$ weight gain/ Total feed consumption

Feed Intake (FI):

Amount of consumed feed all period.

Protein Efficiency Ratio (PER):

PER = body weight gain $(\mathrm{g}) /$ protein intake $(\mathrm{g})$.

Protein Retention Efficiency (PRE, \%):

PRE $(\%)=100$ [Retained protein $(\mathrm{g}) /$ protein intake].

Survival (S\%):

$\mathrm{S}(\%)=\mathrm{Nt} / \mathrm{N} 0 \times 100$
Where; $\mathrm{Nt}=$ Total number of fish survived in tank at end of experiment.

$\mathrm{N} 0=$ Total number of fish survived in tank at beginning of experiment. According to (Harrell et al., 1990).

\section{Economical Evaluation:}

Feed cost of kg: Calculated from the price of feed ingredient and the cost per $\mathrm{kg}$ gain (FCR $\times$ price of $\mathrm{kg}$ feed). The changes were calculated as a percentage from the highest value. Cost of $1 \mathrm{~kg}$ ingredients used were 3.20 L.E. and 10 L.E. for potassium diformate. Egypt Feed Ingredients Price at start of 2012.

\section{Statistical analysis:}

The data obtained in this study were analyzed by one-way ANOVA procedure of Statisticsal Analysis System (SAS Institute, 1998). Means were compared by Duncan's new multiple range test (Duncan, 1955).

\section{RESULTS AND DISCUSSION}

Averages of initial body weight of fish groups at the beginning of the experiment were within range $5 \pm 0.5 \mathrm{~g}$ (Table 2). The differences among the groups were insignificant $(\mathrm{P}>0.05)$ indicating the homogeneity of the experimental groups at the beginning of the experiment. The group of monosex Nile tilapia fingerlings fed diet 3 which containing $0.3 \% \mathrm{KDF}$ had a significantly $(\mathrm{P}<0.05)$ highest $\mathrm{BW}$ compared to other groups throughout the experimental period followed by the group of monosex Nile tilapia fingerlings fed the other diets 4, 2 and 1, respectively. This finding is in agreement with Ringø (1992) in Arctic charr (Salvelinus alpinus) and CuvinAralar et al. (2011) in juvenile male Nile tilapia (Oreochromis niloticus).

Also, it was found that the group of monosex Nile tilapia fingerlings fed on diet 3 had highest feed intake then the rest of experimental groups. While the control group had the lowest feed intake than the rest of experimental group in agreement with Ramli et al. (2005) reported that potassium diformate significantly increased feed intake $(\mathrm{P}<0.01)$.

There was a trend of increasing growth performance with increasing inclusion level of KDF at $0.3 \%$ on the basis of final body weight, weight gain and specific growth rate (SGR). These results indicated that the best BWG values were obtained at the end of experiment for the fish fed diet 3 followed in a decreasing order by those fed on diets 4, 2 and 1 respectively (Table 2). Similar results were obtained by Ramli et al. (2005) in Nile tilapia and Zhou et al. (2009) in hybrid tilapia (Oreochromis niloticus $\mathrm{x}$ Oreochromis aureus) fingerlings. In addition, same trend was found on the result of SGR which indicated that the highest SGR at the end of the experimental period was recorded in the group of monosex Nile tilapia fingerlings fed diet 3 followed in a decreasing order by diets 4,2 and 1 respectively indicated that the highest SGR at the end of the experimental period was found in the group of monosex Nile tilapia fingerlings fed diet 3 followed in a decreasing order by diets 4, 2 and 1 respectively. This may be due to that potassium diformate (K-diformate, KDF) is odorless, low-corrosive, flow able (Hebeler et al., 2000) or more palatable to fish and dietary inclusion has demonstrated effectiveness in enhancing growth 
performance of terrestrial animals (Øverland et al., 2000; Canibe et al., 2001; Mroz et al., 2002). Similar results were obtained by Christiansen and Lückstädt (2008) in Atlantic salmon (Salmo salar).

These results indicated that the best value of FCR values were obtained for group of monosex Nile tilapia fingerlings fed diet 3 followed by diets 4,2 and 1 respectively (Table 2 ). These results indicated that the highest FE values were obtained for group of monosex Nile tilapia fingerlings fed diet 3 than diets 4, 2 and 1 respectively. Similar results were obtained by Ramli et al. (2005). They reported that potassium diformate improved the feed conversion ratio significantly $(\mathrm{P}$ $>0.05$ ). Owen et al. (2006) tested the sodium salt of butyric acid as a feed additive in the African catfish (Clarias gariepinus) at $0.2 \%$ in two diets. They reported that FCR was improved in catfish. Also, Christiansen and Lückstädt (2008) reported that the addition of 0.8 and $1.4 \% \mathrm{KDF}$ in the diets of Atlantic salmon (Salmo salar) resulted in significantly $(\mathrm{P}>0.05)$ better FCR after 126 days of rearing. Liebert et al. (2010) reported that when $0.3 \%$ of sodium diformate was added to the diet of the tilapia fingerlings (Oreochromis niloticus), feed conversion ratio significantly improved. Cuvin-Aralar et al. (2011) reported that the supplementation of either KDF or NDF significantly $(\mathrm{P}>0.05)$ improved feed conversion of male Nile tilapia compared to the control group, these results are in agreement with the present study.
The highest PER values were obtained for group of monosex Nile tilapia fingerlings fed diet 3 followed in a decreasing order by diets 4, 2 and 1 respectively. Similar results were obtained by Ramli et al. (2005) reported that protein efficiency ratio was also significantly $(\mathrm{P}<0.05)$ improved due to the addition of the formic acid salt. The improvement was superior with $0.2 \%$ and $0.5 \%$ addition of potassium diformate. This result was in agreement with Lückstädt and Schulz (2008) and Storebakken et al. (2010) due to higher protein digestibility.

These results indicated that the highest PRE values were obtained for group of monosex Nile tilapia fingerlings fed diet 3 followed in a decreasing order by diets 2, 4 and 1, respectively. A similar result was obtained by Liebert et al. (2010) showed that when $0.3 \%$ of sodium diformate was added in the diet of the tilapia fingerlings (Oreochromis niloticus), protein retention efficiency improved significantly.

There were significant differences $(\mathrm{P}<0.05)$ in survival rate among group of monosex Nile tilapia $(O$. niloticus) fingerlings fed different KDF level. The group of monosex Nile tilapia fingerlings fed diet $3(0.3 \%$ $\mathrm{KDF}$ ) had a highest survival rate $100 \%$. While the group of fingerlings fed diet 1 (Control) and 2 had a lowest survival rate $93 \%$ (Table 2). In agreement with Ramli et al. (2005) concluded that the use of potassium diformate at $0.2 \%$ is an efficient tool to control V. anguillarum in tropical tilapia culture.

Table (1): Diet composition and chemical composition (\%) used in experiment

\begin{tabular}{|c|c|c|c|c|}
\hline \multirow{2}{*}{ Feed Ingredients } & \multicolumn{4}{|c|}{ Experimental Diets } \\
\hline & 1 (Control) & $2(0.1 \%$ KDF $)$ & $3(0.3 \%$ KDF $)$ & $4(0.5 \%$ KDF $)$ \\
\hline Fish meal & 20 & 20 & 20 & 20 \\
\hline Corn gluten & 60 & 60 & 60 & 60 \\
\hline Soybean meal & 330 & 330 & 330 & 330 \\
\hline Wheat Mill run & 130 & 130 & 130 & 130 \\
\hline Rice bran & 140 & 140 & 140 & 140 \\
\hline Yellow corn & 250 & 249 & 247 & 245 \\
\hline DCP (Di calcium phosphate) 1 & 10 & 10 & 10 & 10 \\
\hline Vitamin \& Mineral Mix2 & 20 & 20 & 20 & 20 \\
\hline C.M.C3 & 20 & 20 & 20 & 20 \\
\hline Soybean oil & 20 & 20 & 20 & 20 \\
\hline Potassium diformate4 & - & 1 & 3 & 5 \\
\hline TOTAL & 1000 & 1000 & 1000 & 1000 \\
\hline \multicolumn{5}{|l|}{ Chemical Composition (\%) } \\
\hline Moisture & 10.62 & 10.50 & 10.31 & 10.44 \\
\hline Crude protein & 25.13 & 25.30 & 25.00 & 25.22 \\
\hline Ether extract & 7.71 & 7.82 & 7.63 & 7.75 \\
\hline Crude fiber & 6.24 & 6.16 & 6.1 & 6.05 \\
\hline Ash & 7.05 & 7.1 & 7.12 & 7.16 \\
\hline N.F.E5 & 43.25 & 43.12 & 43.84 & 43.38 \\
\hline Gross energy Kcal/ 100g6 & 392.60 & 394.07 & 393.54 & 394.02 \\
\hline $\mathrm{P} / \mathrm{E}$ ratio $\mathrm{CP} / \mathrm{GE} 7$ & 64.01 & 64.20 & 63.53 & 64.01 \\
\hline
\end{tabular}

\section{DCP (Di calcium phosphate)}

Each Kg vitamin \& mineral mixture premix contained Vitamin A, 4.8 million IU, D3, 0.8 million IU; E, 4 g; K, 0.8 g; B1, 0.4 g; Riboflavin, 1.6 g; B6, 0.6 g, B12, 4 mg; Pantothenic acid, 4 g; Nicotinic acid, 8 g; Folic acid, 0.4 g Biotin,20 mg , Mn, 22 g; Zn, 22 g; Fe, 12 g; Cu, 4 g; I, 0.4 g, Selenium, $0.4 \mathrm{~g}$ and $\mathrm{Co}, 4.8 \mathrm{mg}$.

Carboxyl methyl cellulose

AQUAFORM ${ }^{\circledR}(\mathrm{KDF})$ ADDCON, Germany

Nitrogen Free Extract $=100-(\%$ Protein $+\%$ Fat $+\%$ Fiber $+\%$ Ash $)$.

Gross Energy calculated based on protein $(5.65 \mathrm{Kcal} / \mathrm{g})$, fat $(9.45 \mathrm{Kcal} / \mathrm{g})$ and carbohydrate $(4.11 \mathrm{Kcal} / \mathrm{g})$. According to (NRC, 2011$)$.

Protein Energy Ratio. ( crud protein mg / GE Kcal ). 


\section{Body Composition}

The effects of different levels of KDF in dietary monosex Nile tilapia fingerlings on body chemical analysis are presented in (Table 3 ). It was observed that the best protein content was obtained in group of monosex Nile tilapia fingerlings fed diet $3(0.3 \% \mathrm{KDF})$ than the rest of experimental groups. In agreement with Rahman et al. (2008). While the lowest means of ether extract and ash content were found in group of fish fed diet 3. There were no significant differences $(\mathrm{P}>0.05)$ in moisture contents in all treatments at the end experiment. Similar results were obtained by $\mathrm{Ng}$ et al. (2009).

\section{Economic Evaluation}

Calculations of economical efficiency of the tested diets based on the cost of feed, costs of one $\mathrm{Kg}$ gain in weight and its ratio with the control group are shown in Table (4). The lowest Feed cost $/ 1 \mathrm{Kg}$ gain $(4.68 \mathrm{LE})$ followed by group of fish fed diets 4,2 and 1 (control) respectively. The percent of feed cost of $\mathrm{Kg}$ gain relative to the control $100 \%$ were $83 \%$ in group of fish fed diet $3(0.3 \% \mathrm{KDF})$ followed by group of fish fed diets 4 (0.5\% KDF) $94 \%$, and $2(0.1 \% \mathrm{KDF}) 95 \%$ respectively.

Table (2): Means growth performance, feed intake, nutrient efficiency and survival rate of monosex Nile tilapia fingerlings $(O$. niloticus $)$ fed different levels of potassium diformate for 84 days.

\begin{tabular}{lllll}
\hline \multicolumn{1}{c}{ Parameter } & \multicolumn{4}{c}{ Diet No. } \\
\cline { 2 - 5 } & \multicolumn{1}{c}{$\mathbf{1}($ Control ) } & $\mathbf{2}(\mathbf{0 . 1 \%}$ KDF $)$ & $\mathbf{3 ~ ( 0 . 3 \% ~ K D F ~ ) ~}$ & $\mathbf{4}(\mathbf{0 . 5 \%}$ KDF ) \\
\hline Average Initial Body Weight(g) & $5^{\mathrm{a}} \pm 0.49$ & $5.2^{\mathrm{a}} \pm 0.54$ & $5.1^{\mathrm{a}} \pm 0.89$ & $5^{\mathrm{a}} \pm 0.75$ \\
Average Final Body Weight (g)) & $17^{\mathrm{c}} \pm 0.68$ & $20^{\mathrm{c}} \pm 0.32$ & $29^{\mathrm{a}} \pm 0.65$ & $23^{\mathrm{b}} \pm 0.52$ \\
Average Body Weight gain (g) & $12^{\mathrm{c}} \pm 0.46$ & $15^{\mathrm{b}} \pm 0.35$ & $24^{\mathrm{a}} \pm 0.66$ & $18^{\mathrm{b}} \pm 0.55$ \\
Specific Growth Rate (SGR) (\%/day) & $1.46^{\mathrm{c}} \pm 0.21$ & $1.60^{\mathrm{b}} \pm 0.44$ & $2.07^{\mathrm{a}} \pm 0.61$ & $1.82^{\mathrm{b}} \pm 0.40$ \\
Feed Intake (FI) (g) & $21.2^{\mathrm{c}} \pm 0.87$ & $24.8^{\mathrm{b}} \pm 0.94$ & $34.6^{\mathrm{a}} \pm 0.86$ & $29.4^{\mathrm{b}} \pm 0.93$ \\
Feed Conversion Ratio (FCR) & $1.77^{\mathrm{c}} \pm 0.52$ & $1.68^{\mathrm{b}} \pm 0.50$ & $1.45^{\mathrm{a}} \pm 0.37$ & $1.63^{\mathrm{b}} \pm 0.43$ \\
Feed Efficiency (FE) & $0.57^{\mathrm{c}} \pm 0.29$ & $0.60^{\mathrm{b}} \pm 0.31$ & $0.69^{\mathrm{a}} \pm 0.29$ & $0.61^{\mathrm{b}} \pm 0.31$ \\
Protein Efficiency Ratio (PER) & $2.52^{\mathrm{c}} \pm 0.40$ & $2.64^{\mathrm{b}} \pm 0.37$ & $3.08^{\mathrm{a}} \pm 0.37$ & $2.71^{\mathrm{b}} \pm 0.64$ \\
Protein Retention Efficiency (PRE) & $34.35^{\mathrm{c}} \pm 0.31$ & $36.36^{\mathrm{b}} \pm 0.26$ & $40.74^{\mathrm{a}} \pm 0.53$ & $35.56^{\mathrm{b}} \pm 0.89$ \\
Survival Rate (\%) & $93^{\mathrm{c}}$ & $93^{\mathrm{c}}$ & $100^{\mathrm{a}}$ & $97^{\mathrm{b}}$ \\
\hline
\end{tabular}

${ }^{*}$ Means in the same row having the same superscript letter are not significantly different $(\mathrm{P}>0.05)$.

Table (3): Effect of different levels of potassium diformate on body composition (\% dry weight) of monosex Nile tilapia fingerlings $O$. niloticus at the start and end of the experiment (84 Day, Means $\pm \mathrm{SD}$ ).

\begin{tabular}{lccccc}
\hline \multirow{2}{*}{ Item } & \multirow{2}{*}{ at Initial } & \multicolumn{5}{c}{ Diet No. } \\
\cline { 3 - 6 } & & $\mathbf{1}(\mathbf{C o n t r o l})$ & $\mathbf{2}(\mathbf{0 . 1 \%} \mathbf{K D F})$ & $\mathbf{3}(\mathbf{0 . 3 \%} \mathbf{K D F})$ & $\mathbf{4}(\mathbf{0 . 5 \%} \mathbf{K D F})$ \\
\hline Moisture & 77.20 & $73.4 \mathrm{a} \pm 1.63$ & $72.96 \mathrm{a} \pm 1.22$ & $73.33 \mathrm{a} \pm 1.35$ & $73.95 \mathrm{a} \pm 1.42$ \\
\hline \multicolumn{2}{c}{ at end of the experiment } & & & & \\
\hline Crude Protein & 49.31 & $52.12 \mathrm{~b} \pm 0.73$ & $52.72 \mathrm{~b} \pm 0.54$ & $56.18 \mathrm{a} \pm 0.62$ & $51.94 \mathrm{~b} \pm 0.26$ \\
Ether extract & 30.51 & $31.23 \mathrm{~b} \pm 0.26$ & $31.12 \mathrm{~b} \pm 0.38$ & $30.34 \mathrm{a} \pm 0.51$ & $31.20 \mathrm{~b} \pm 0.37$ \\
Ash & 20.18 & $16.65 \mathrm{~b} \pm 0.32$ & $16.16 \mathrm{~b} \pm 0.24$ & $13.48 \mathrm{a} \pm 0.31$ & $16.86 \mathrm{~b} \pm 0.23$ \\
\hline
\end{tabular}

Note: Values are means \pm SE of three replications. Means in the same row having different superscripts are significantly different $(\mathrm{P}<0.05)$.

Table (4): Economic analysis of Nile tilapia fingerlings (O. niloticus) fed different levels of potassium diformate for 84 days.

\begin{tabular}{lcccc}
\hline & \multicolumn{4}{c}{ Diet No. } \\
\cline { 2 - 5 } & $\mathbf{1}$ (Control) & $\mathbf{2 ~ ( 0 . 1 \% ~ K D F ) ~}$ & $\mathbf{3}(\mathbf{0 . 3 \%}$ KDF) & $\mathbf{4}(\mathbf{0 . 5 \%}$ KDF) \\
\hline Cost of Kg diets (L.E) & 3.20 & 3.21 & 3.23 & 3.25 \\
Feed Cost /1 kg fish gain(L.E) & 5.65 & 5.38 & 4.68 & 5.31 \\
Relative \% of feed cost of Kg gain & 100 & 95 & 83 & 94 \\
\hline
\end{tabular}




\section{IN CONCLUSION}

It was found that the best group of fish fed $\operatorname{KDF}(0.3 \%)$ in term of growth performance, feed utilization and economic analysis under this experimental condition.

\section{REFERENCE}

A. O. A. C. (1995). Association of official analytical chemists, official methods of analysis. 16 th edition, AOAC, Arlington, VA. 1832.

Canibe N., Steien S. H., Øverland M. and Jensen B. B. (2001). Effect of K-diformate in starter diets on acidity, microbiota, and the amount of organic acids in the digestive tract of piglets, and on gastric alterations. J. Anim. Sci., 79: 2123-2133.

Christiansen R. and Lückstädt C. (2008). Effects of different dosages of potassium diformate in fishmeal on the performance of Atlantic salmon Salmo salar. World Aquaculture Society Conference, Busan, Korea, Abstract CD-Rom, p. 467.

Cuvin-Aralar M. L. A., Lückstädt C., Schroeder K. and Kühlmann K.-J. (2011). Effect of dietary organic acid salts, potassium diformate and sodium diformate on the growth performance of male Nile tilapia Oreochromis niloticus. Bulletin of Fish Biology, 13 (1/2): 33-40

Duncan, D. B. (1955). Multiple range ad multiple F- test. Biometrics, 11: 1- 42.

El-Sayed A.-F. M., Abdel-Aziz S. H. and Abdel-Ghani H. M. (2012). Effects of phytoestrogens on sex reversal of Nile tilapia (Oreochromis niloticus) larvae fed diets treated with $17 \alpha$-ethyltestosterone. Aquaculture, 360-361: 58-63.

Février C., Gotterbarm G., Jaghelin-Peyraud U., Lebreton Y., Legouvec F. and Aumaitre A. (2001). Effects of adding potassium diformate and phytase excess for weaned piglet. In: Lindberg, J.E., Ogle, B. (Eds.), Digestive Physiology of Pigs. CABI Publishing, Oxon, UK, pp. 136-138.

GAFRD (2011). Book of Fishery Statistics. General Authority for Fish Resource Development, Cairo, Egypt.

Gjerde B., Mengistue S.B., Odegard J., Johansen H. and Altairano D.S. (2012). Quantitative genetics of body weight, fillet weight and fillet yield in Nile tilapia (Orechromis niloticus). Aquaculture, 342 343: 117-124.

Harrell R. M., Kerby J. H. and Minton R.V. (1990). Culture and Propagation of Striped bass and it's hybrids striped bass, Committee, southern division, American Fisheries Society, Bethesda, Maryland.

Hebeler D., Kulla S., Winkenwerder F., Kamphues J., Zentek J. and Amtsberg G. (2000). Influence of a formic-acid-potassium-formate-complex on chime composition as well as on the intestinal microflora of weaned piglets. Hannover 54th Proc. Soc. Nutr. Physiol. Göttingen, Germany. March 7-9, 2000.
Kirchgessner M., von Gedek B., Wiehelr S., Bott A., Eidelsburger U. and Roth F.X. (1992). Influence of formic acid, calciumformate and sdiumhydrogencarbonate on the microflora in different segments of the gastrointestinal tract. Communication. Investigations about the nutritive efficacy of organic acids in the rearing of piglets. J.Anim. Physiol. Anim. Nutr.,68:73-1.

Liebert F., Mohamed K. and Lückstädt C. (2010). Effects of diformates on growth and feed utilization of all male Nile Tilapia fingerlings (Oreochromis niloticus) reared in tank culture. XIV International Symposium on Fish Nutrition and Feeding, Qingdao, China, Book of Abstracts (190 pp.).

Lückstädt C. and Schulz C. (2008). The dietary effects of potassium diformate on the protein and fat digestibility of Atlantic salmon (Salmo salar) reared in sea water. Aquaculture Europe, Krakow, Poland, September 15-18, 2008. Short Communications, p. 391-392.

Lueck E. (1980). Antimicrobial food additives: characteristics, uses and effects. In: Lueck, E. (Ed.), Antimicrobial Food Additives. SpringVerlag, New York, USA, pp. 35-197.

Mroz Z., Reese D. E., Øverland M., van Diepen J. T. M. and Kogut J. (2002). The effects of potassium diformate and its molecular constituents on the apparent ileal and fecal digestibility and retention of nutrients in growing-finishing pigs. J. Anim. Sci., 80: 681-690.

Ng W.-K., Chik-Boon K., Kumar S. and Siti-Zahrah A. (2009). Effects of dietary organic acids on growth, nutrient digestibility and gut microflora of red hybrid tilapia, Oreochromis sp., and subsequent survival during a challenge test with Streptococcus agalactiae. Aquaculture Research, 40: $1490-1500$.

NRC (National Research Council). (2011). Nutrient requirements of fish. Committee on Animal Nutrition Board on Agriculture. National Academy Press, Washington D. C, USA. p.114

Øverland M., Granli T., Kjos N.P., Fjetland O., Steien S.H. and Stokstad M. (2000). Effect of dietary formates on growth performance, carcass traits, sensory quality, intestinal microflora, and stomach alterations in growing-finishing pigs. Journal of Animal Science, 78: 1875-1884.

Owen M. A. G., Waines P., Bradley G. and Davies S. (2006). The effect of dietary supplementation of sodium butyrate on the growth and microflora of Clarias gariepinus (Burchell 1822). Abstract, XII International Symposiumon Fish Nutrition and Feeding, Biarritz, France, pp. 149

Rahman M. S., Howlider M. A. R., Mahiuddin M. and Rahman M. M. (2008). Effect of supplementation of organic acids on laying performance, body fatness and egg quality of hens. Bang. J. Anim. Sci., 37(2): $74-81$

Ramli N., Heindl U. and Sunanto S. (2005). Effect of potassium-diformate on growth performance of tilapia challenged with Vibrio anguillarum. 
Abstract from World Aquaculture Society Conference, May 9-13, 2005, Bali, Indonesia.

Ringø E. (1992). Effects of dietary formate and acetate on growth and lipid digestibility in Arctic charr, Salvelinus alpinus (L.). Fiskeridirektoratets Skrifter. Serie Ernaering, 5: 17-24.

SAS Institute (1998). SAS statistical guide for personal computer, SAS Institute Inc. Cary, NC.

Storebakken T., Berge G. M., Øverland M., Shearer K. D., Hillestad M. and Krogdahl A. (2010). Dietary potassium diformate protects against heat-induced reduction of protein digestibility in a mixture of full-fat soy and wheat when used in extruded diets for Atlantic salmon (Salmo salar L). 14th Symposium on Fish Nutrition \& Feeding, p. 522 (Qingdao, China).

Thodesen J., Rye M., Wong Y., Yang K., Benston H. and Giedrem T. (2011). Genetic improvement of tilapias in China: genetic parameters and selection responses in growth of Nile tilapia (Oreochromis niloticus) after six generations of multi-trait selection for growth and fillet yield. Aquaculture, 322-323: 51-64.

Thodesen J., Rye M., Wong Y., Yang K., Benston H. and Giedrem T. (2012). Genetic improvement of tilapias in China: genetic parameters and selection responses in growth of Nile tilapia (Oreochromis niloticus) after six generations of multi-trait selection for growth and fillet yield. Aquaculture, 366-367: 67-75.

Wilson R. P. (1991). Handbook of nutrient requirements of finfish. Page 196 in R.P. Willson, editor. Taylor and Francis, CRC Press Inc., Oxford, UK.

Zhou Z., Liu Y., He S., Shi P., Gao X., Yao B. and Ringø E. (2009). Effects of dietary potassium diformate (KDF) on growth performance, feed conversion and intestinal bacterial community of hybrid tilapia (Oreochromis niloticus $\times$ O. aureus). Aquaculture, 291: 89-94.

\section{تأثثير التركيزات المختلفة من البوتاسيوم داى فورمات على أداء النمو والاستفادة الغذائية لاصبعيات سمك

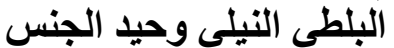

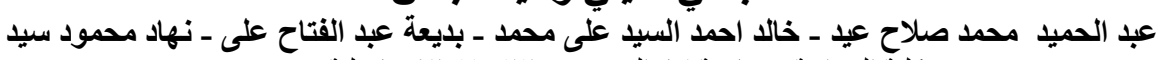

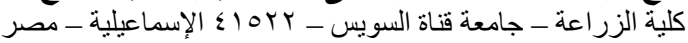

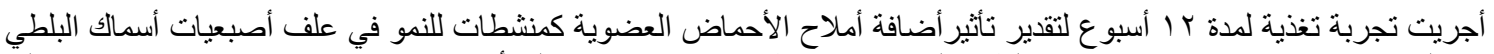

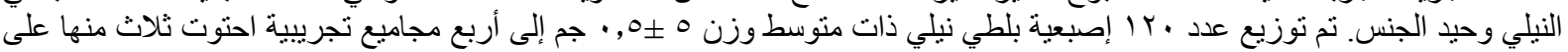

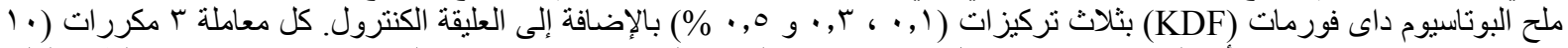

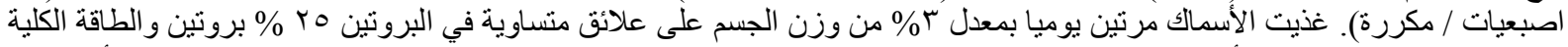

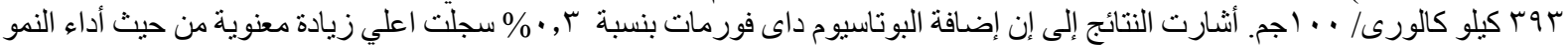

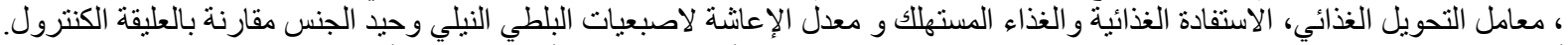

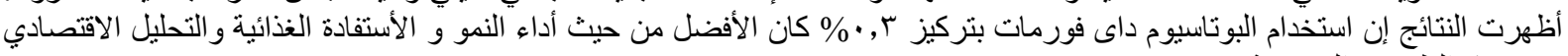
تحت هذه الظروف التجريبية. 